University of Nebraska - Lincoln

DigitalCommons@University of Nebraska - Lincoln

Spring Wheat Response to Tillage and Nitrogen Fertilization in Rotation with Sunflower and Winter Wheat

Ardell D. Halvorson

USDA-ARS, adhalvor@lamar.colostate.edu

Alfred L. Black

USDA-ARS

Joseph M. Krupinsky

USDA-ARS

Steven D. Merrill

USDA-ARS

Brian J. Wienhold

University of Nebraska-Lincoln, Brian.Wienhold@ars.usda.gov

See next page for additional authors

Follow this and additional works at: https://digitalcommons.unl.edu/usdaarsfacpub

Halvorson, Ardell D.; Black, Alfred L.; Krupinsky, Joseph M.; Merrill, Steven D.; Wienhold, Brian J.; and Tanaka, Donald L., "Spring Wheat Response to Tillage and Nitrogen Fertilization in Rotation with Sunflower and Winter Wheat" (2000). Publications from USDA-ARS / UNL Faculty. 1180.

https://digitalcommons.unl.edu/usdaarsfacpub/1180

This Article is brought to you for free and open access by the U.S. Department of Agriculture: Agricultural Research Service, Lincoln, Nebraska at DigitalCommons@University of Nebraska - Lincoln. It has been accepted for inclusion in Publications from USDA-ARS / UNL Faculty by an authorized administrator of DigitalCommons@University of Nebraska - Lincoln. 


\section{Authors}

Ardell D. Halvorson, Alfred L. Black, Joseph M. Krupinsky, Steven D. Merrill, Brian J. Wienhold, and Donald L. Tanaka 


\title{
SOIL MANAGEMENT
}

\section{Spring Wheat Response to Tillage and Nitrogen Fertilization in Rotation with Sunflower and Winter Wheat}

\author{
Ardell D. Halvorson, * Alfred L. Black, Joseph M. Krupinsky, Steven D. Merrill, \\ Brian J. Wienhold, and Donald L. Tanaka
}

\begin{abstract}
Spring wheat (Triticum aestivum $\mathrm{L}$.) is a major crop in the northern Great Plains that is generally grown following a 21-mo fallow period. A 12-yr study was conducted to determine the effects of tillage system [conventional-till (CT), minimum-till (MT), and no-till (NT)], N fertilizer rate (34, 67, and $101 \mathrm{~kg} \mathrm{~N} \mathrm{ha}^{-1}$ ), and cultivar (Butte86 and Stoa) on spring wheat yields within a dryland spring wheat (SW)-winter wheat (WW)-sunflower (Helianthus annuus L.) (SF) rotation. Grain yield responses varied with tillage system, $\mathbf{N}$ fertilizer rate, cultivar, and year as indicated by significant tillage $\times N$ rate $\times$ year and $N$ rate $\times$ cultivar $\times$ year interactions. In years with $>260 \mathrm{~mm}$ total plant available water (TPAW) but $<\mathbf{4 0 0} \mathbf{~ m m}$ TPAW, NT grain yields were greater than those with $\mathrm{CT}$ at the highest $\mathrm{N}$ rate, with similar trends at the medium and low $N$ rates. When TPAW exceeded $400 \mathrm{~mm}$, grain yields for $\mathrm{CT}$ were generally greater than for NT at the medium $\mathrm{N}$ rates. The greatest 12-yr average grain yield $\left(1727 \mathrm{~kg} \mathrm{ha}^{-1}\right)$ was obtained with NT and application of $101 \mathrm{~kg} \mathrm{~N} \mathrm{ha}^{-1}$. Grain yields were lowest during years when TPAW was $<300 \mathrm{~mm}$, with only small responses to tillage and $\mathbf{N}$ treatments. Cultivars responded similarly to $\mathbf{N}$ fertilization in years with $>300 \mathrm{~mm}$ TPAW, with Butte86 yielding more than Stoa in 6 out of the $12 \mathrm{yr}$. Soil $\mathrm{NO}_{3}-\mathrm{N}$ levels increased in the root zone following three consecutive drought years, but had declined to initial year levels by the end of the study. These results indicate that farmers in the northern Great Plains can produce SW following SF in annual cropping systems that do not include a fallow period, particularly if NT or MT systems are used with adequate $\mathbf{N}$ fertilization.
\end{abstract}

$\mathrm{I}$ $\mathrm{N}$ the semi-arid northern Great Plains, plant-available water (PAW) and soil erosion are major factors limiting agricultural production. Therefore, farmers need to manage crop residues and tillage to control soil erosion and effectively store and use the limited precipitation received for crop production. No-till and minimumtill systems are effective steps in efficiently saving more precipitation for crop production (Aase and Schaefer, 1996; Halvorson, 1990b; Peterson et al., 1996; Tanaka and Anderson, 1997).

The traditional crop-fallow system of farming uses water/precipitation inefficiently as evidenced by the development of dryland saline-seeps in the northern Great Plains (Halvorson and Black, 1974). The solution to the saline-seep problem is to crop more intensively with

A.D. Halvorson, USDA-ARS, P.O. Box E, Fort Collins, CO 80522; A.L. Black, J.M. Krupinsky, S.D. Merrill, and D.L. Tanaka, USDAARS, P.O. Box 459, Mandan, ND; and B.J. Wienhold, USDA-ARS, 119 Keim Hall, East Campus, Univ. Nebraska, Lincoln, NE. Contribution from USDA-ARS. Received 26 May 1999. *Corresponding author (adhalvor@lamar.colostate.edu).

Published in Agron. J. 92:136-144 (2000). efficient use of precipitation for crop production (Halvorson, 1990a). Saline-seep areas have been controlled and returned to crop production by growing alfalfa (Medicago sativa L.) and/or by annual cropping of the seep recharge area (Halvorson, 1984; Halvorson and Reule, 1980).

Deibert et al. (1986) suggested that farmers in the northern Great Plains need to use more continuous cropping and less crop-fallow to attain more efficient use of limited water supplies. Peterson et al. (1996) and McGee et al. (1997) point out that MT and NT fallow systems have a high percentage of the soil water in the profile recharged by the first spring following harvest. Continuing the fallow period for an additional 5 to $12 \mathrm{mo}$ is very inefficient and costly. Therefore, cropping more intensively than crop-fallow is needed to efficiently use the water stored by NT and MT systems. Improved precipitation-storage efficiency with MT and NT allows producers the option of cropping more intensively than with crop-fallow (Halvorson and Reule, 1994; Peterson et al., 1996). Black et al. (1981) reported more efficient water use with more intensive cropping systems. Halvorson and Black (1985) reported crop yields that were generally $>80 \%$ of 2 -yr SW-fallow yields when grown in an annual cropping system with adequate $\mathrm{N}$ and $\mathrm{P}$ fertilization. Aase and Reitz (1989) and Aase and Schaefer (1996) reported that annually cropped SW with NT was more profitable and productive than SW-fallow in a $356 \mathrm{~mm}$ precipitation zone in northeast Montana.

Hall and Cholick (1989) reported varying responses of SW cultivars to tillage systems and a need to select cultivars for use under NT conditions. Most SW cultivars developed for use in the northern Great Plains have been developed using crop-fallow systems and low residue, CT environments.

Information is limited on the successes of more intensive dryland cropping systems in the northern Great Plains that include MT and NT management systems and a deep rooted crop, such as SF, in the rotation. In addition to more efficient water use, more intensive MT and NT cropping systems have the potential to be more profitable (Dhuyvetter et al., 1996) and reduce soil erosion potential (Merrill et al., 1999). This study was undertaken to determine the effects of tillage system (CT, MT, NT), $\mathrm{N}$ fertilizer rate (34, 67, and $101 \mathrm{~kg} \mathrm{~N} \mathrm{ha}^{-1}$ ),

Abbreviations: CT, conventional-till; MT, minimum-till; NT, no-till; PAW, plant-available water; SW, spring wheat; TPAW, total plantavailable water; $\mathrm{WW}$, winter wheat; $\mathrm{SF}$, sunflower. 


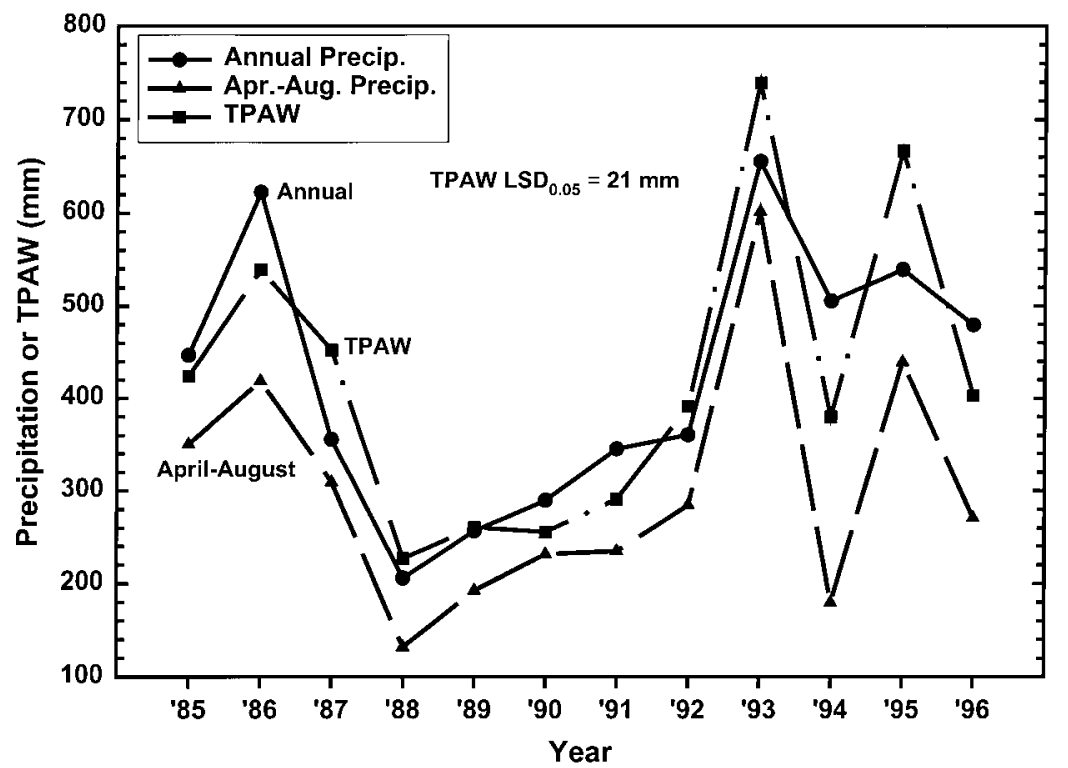

Fig. 1. Annual and growing season (April through August) precipitation and total plant available water (TPAW) for each year at the study site.

and cultivar (Butte86 and Stoa) on SW grain yields within a dryland SW-WW-SF rotation.

\section{METHODS AND MATERIALS}

The study was initiated in 1984 on a Temvik-Wilton silt loam soil (fine-silty, mixed, superactive, frigid Typic and Pachic Haplustolls) located near Mandan, ND. Surface soil $\mathrm{pH}$ was 6.4 , soil organic carbon was $21.4 \mathrm{~g} \mathrm{~kg}^{-1}$, and soil test $\mathrm{P}$ was 20 to $26 \mathrm{mg} \mathrm{kg}^{-1}$ in the spring of 1984 (Black and Tanaka, 1997). Data collection was from 1985 through 1996. An annual cropping rotation, SW-WW-SF, was managed under three tillage systems, CT, MT, and NT (Halvorson et al., 1999a, b). Nitrogen fertilizer was applied in early spring each year as a broadcast application of $\mathrm{NH}_{4} \mathrm{NO}_{3}$ at rates of 34, 67, and $101 \mathrm{~kg} \mathrm{~N} \mathrm{ha}^{-1}$, except for 1991 and 1992 when no $\mathrm{N}$ was applied because of a build-up of residual soil $\mathrm{NO}_{3}-\mathrm{N}$ due to drought conditions and low yields from 1988 to 1990. Phosphorus fertilizer was applied broadcast at a rate of $40 \mathrm{~kg} \mathrm{P} \mathrm{ha}{ }^{-1}$ at the beginning of the study in October 1983. Soil test $\mathrm{P}$ levels in the 0 - to $15-\mathrm{cm}$ depth averaged $16 \mathrm{mg} \mathrm{kg}^{-1}$ in 1991 and $11 \mathrm{mg} \mathrm{kg}^{-1}$ in 1996. Two SW cultivars with good yield potential, Butte86 and Stoa, were used throughout the study. Each main block of the study was 137.2 by $73.1 \mathrm{~m}$ in size. Tillage plots $(45.7 \times 73.1 \mathrm{~m})$ were oriented in a north-south direction, $\mathrm{N}$ plots $(137.2 \times 24.4 \mathrm{~m})$ in an east-west direction across all tillage plots, and cultivars $(22.9 \times 73.1 \mathrm{~m})$ in a north-south direction within tillage plots and across all $\mathrm{N}$ plots. The smallest plot with the combination of all variables was 22.9 by $24.4 \mathrm{~m}$. Triplicate sets of plots were established to allow all phases of the rotation to be present each year. Experimental design was a strip-strip-split plot, with tillage and $\mathrm{N}$ rate treatments stripped and cultivar as subplots with 3 replications.

The CT treatments were generally not tilled in the fall after SF harvest but were disked once to a depth of 8 to $12 \mathrm{~cm}$ in the spring prior to SW planting. Surface residue cover was usually $<30 \%$ after planting. Minimum-till treatments were generally not tilled in the fall after SF harvest but were undercut once in the spring with a sweep plow at a shallow depth $(<7.5 \mathrm{~cm})$ prior to SW planting. Surface residue cover was usually 30 to $60 \%$ after planting. No-till treatments were not tilled following SF harvest and received one application of glyphosate [N-(phosphonomethyl)glycine] herbicide just prior
Table 1. Spring soil $\mathrm{NO}_{3}-\mathrm{N}$ levels $(0-$ to $120-\mathrm{cm}$ depth) for the tillage $\times \mathbf{N}$ rate $\times$ year interaction. $\dagger$

\begin{tabular}{|c|c|c|c|c|}
\hline \multirow[b]{2}{*}{ Year } & \multirow[b]{2}{*}{ N Rate } & \multicolumn{3}{|c|}{ Soil $\mathrm{NO}_{3}-\mathbf{N}$} \\
\hline & & $\mathbf{C T} \nrightarrow$ & MT & NT \\
\hline \multirow{4}{*}{1985} & & $-\mathbf{k}$ & & \\
\hline & 34 & 66 & 66 & 66 \\
\hline & 67 & 61 & 61 & 61 \\
\hline & 101 & 61 & 61 & 61 \\
\hline \multirow[t]{3}{*}{1986} & 34 & 47 & 49 & 45 \\
\hline & 67 & 46 & 44 & 48 \\
\hline & 101 & 66 & 41 & 52 \\
\hline \multirow[t]{3}{*}{1987} & 34 & 16 & 13 & 16 \\
\hline & 67 & 22 & 20 & 19 \\
\hline & 101 & 40 & 36 & 14 \\
\hline \multirow[t]{3}{*}{1988} & 34 & 14 & 15 & 15 \\
\hline & 67 & 19 & 19 & 18 \\
\hline & 101 & 14 & 27 & 24 \\
\hline \multirow[t]{3}{*}{1989} & 34 & 56 & 48 & 33 \\
\hline & 67 & 132 & 44 & 54 \\
\hline & 101 & 82 & 236 & 105 \\
\hline \multirow[t]{3}{*}{1990} & 34 & 77 & 69 & 19 \\
\hline & 67 & 90 & 71 & 71 \\
\hline & 101 & 243 & 215 & 137 \\
\hline \multirow[t]{3}{*}{1991} & 34 & 157 & 179 & 48 \\
\hline & 67 & 319 & 220 & 145 \\
\hline & 101 & 337 & 432 & 266 \\
\hline \multirow[t]{3}{*}{1992} & 34 & 204 & 173 & 49 \\
\hline & 67 & 339 & 198 & 266 \\
\hline & 101 & 400 & 412 & 188 \\
\hline \multirow[t]{3}{*}{1993} & 34 & 30 & 27 & 20 \\
\hline & 67 & 144 & 57 & 16 \\
\hline & 101 & 282 & 294 & 80 \\
\hline \multirow[t]{3}{*}{1994} & 34 & 108 & 201 & 59 \\
\hline & 67 & 223 & 184 & 71 \\
\hline & 101 & 398 & 140 & 73 \\
\hline \multirow[t]{3}{*}{1995} & 34 & & 60 & \\
\hline & 67 & 51 & 109 & 42 \\
\hline & 101 & 77 & 126 & 47 \\
\hline \multirow{3}{*}{1996} & 34 & 29 & 29 & 28 \\
\hline & 67 & 39 & 43 & 29 \\
\hline & 101 & 52 & 57 & 40 \\
\hline
\end{tabular}

$\dagger$ Interaction $\mathrm{LSD}_{0.05}=96 \mathrm{~kg} \mathrm{~N} \mathrm{ha}^{-1}($ compare tillage within $\mathrm{N} \times$ year); $\mathbf{L S D}_{0.05}=97 \mathrm{~kg} \mathrm{~N} \mathrm{ha}^{-1}$ (compare $\mathbf{N}$ rate within tillage $\times$ year).

$\$$ CT, conventional till; MT, minimum till; NT, no till. 


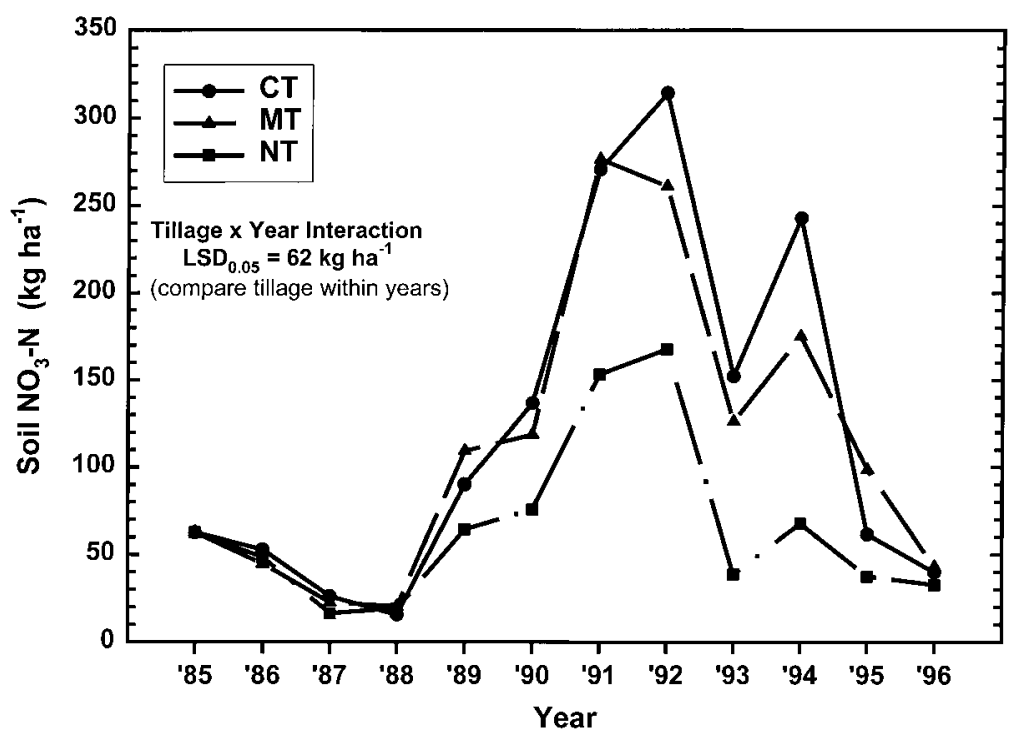

Fig. 2. Spring soil $\mathrm{NO}_{3}-\mathrm{N}$ in 0 - to 120 -cm soil profile as a function of years for conventional-till (CT), minimum-till (MT), and no-till (NT) treatments.

to SW planting in 1985, 1986, 1989, 1990, 1993, and 1994. Surface residue cover was generally $>60 \%$ after planting. No preplant herbicides were applied in the other years. Residue cover estimates were based on visual observations using experience with photographic measurements made of residue cover in adjacent SW-fallow plots (Merrill et al., 1995). Springapplied herbicides were used to control broadleaf and grassy weed species within the growing SW crop. Tillage treatments, agronomic operations, and herbicides applied to the SF and WW crops are described by Halvorson et al. (1999a, 1999b).

The SW was generally planted in early May at a seeding rate of about 3.2-million seeds $\mathrm{ha}^{-1}$ with a NT disk drill with $17.8-\mathrm{cm}$ row spacing. The plots were harvested in mid- to lateAugust each year by hand cutting SW samples for grain yield determination from two $1.5-\mathrm{m}^{2}$ areas within each plot (19851993). In 1994 through 1996, grain yields were determined from a $50-\mathrm{m}^{2}$ area with a plot combine. Grain yields are expressed on a $120 \mathrm{~g} \mathrm{~kg}^{-1}$ water content basis.

Soil samples, one $3-\mathrm{cm}$ diameter core per plot, were collected for gravimetric soil water and $\mathrm{NO}_{3}-\mathrm{N}$ analyses from one cultivar plot for each tillage and $\mathrm{N}$ fertilizer treatment each spring (April) before $\mathrm{N}$ fertilization. Samples were collected in $30-\mathrm{cm}$ increments to a depth of $120 \mathrm{~cm}$. Soil $\mathrm{NO}_{3}-\mathrm{N}$ was determined for each depth increment by autoanalyzer (Lachat Instruments, 1989; Technicon Industrial Systems, 1973) on a 5:1 extract/soil ratio using $2 \mathrm{M} \mathrm{KCl}$ extracting solution (19851992) and a $0.01 \mathrm{M} \mathrm{CaSO}_{4}$ extracting solution (1993-1996). Volumetric soil water content was estimated from gravimetric soil water measurements using a soil bulk density of $1.42 \mathrm{gm} \mathrm{cm}^{-3}$ for the profile (Black and Tanaka, 1997). Total plant available water was estimated as the sum of spring soil PAW in the 0to $120-\mathrm{cm}$ profile plus growing season precipitation (April through August). Spring soil PAW was estimated by subtracting the lowest measured soil water content $(152 \mathrm{~mm})$ in the 0 - to $120-\mathrm{cm}$ profile following SW harvest during the 12 yr study from soil water contents in the 0 - to $120-\mathrm{cm}$ soil profile each spring. Precipitation was measured from April through October each year with a recording rain-gauge at the site. November through March precipitation was estimated from the U.S. Weather Bureau measurements made at the Northern Great Plains Research Laboratory at Mandan, ND, which was located approximately $5 \mathrm{~km}$ northeast of the site.

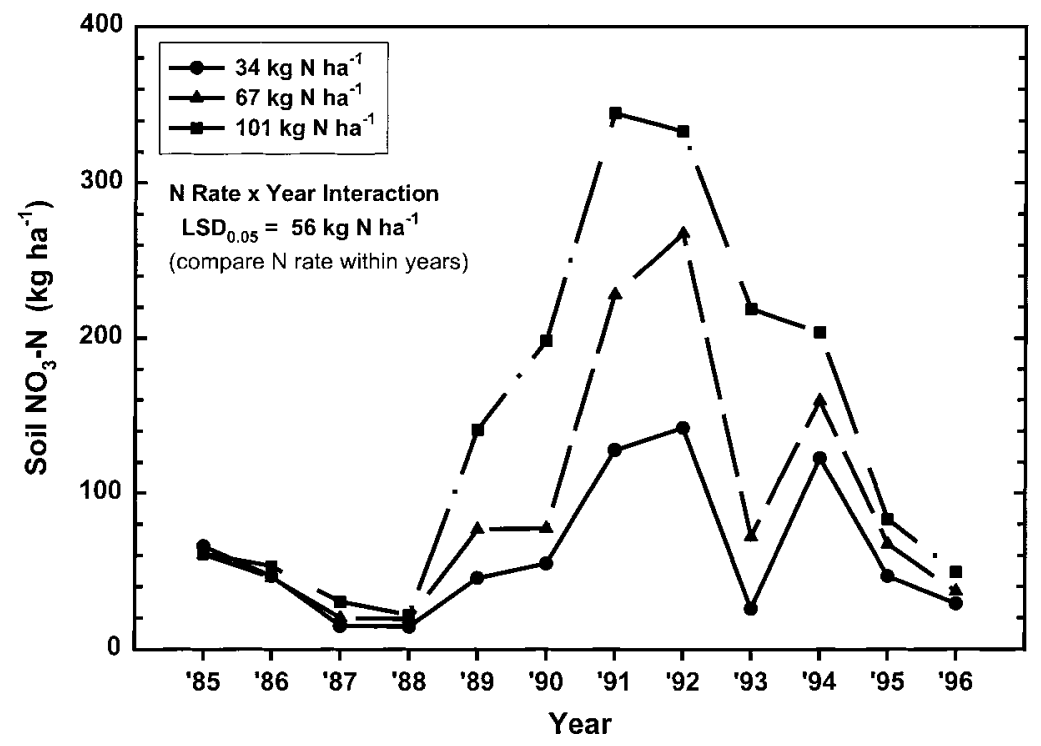

Fig. 3. Spring soil $\mathrm{NO}_{3}-\mathrm{N}$ in 0 - to $120-\mathrm{cm}$ soil profile as a function of years for $\mathrm{N}$ rate treatments. 
Analysis of variance procedures were conducted using SAS statistical procedures (SAS Institute, 1991) with years treated as a fixed variable. All differences discussed are significant at the $P=0.05$ probability level unless otherwise stated. A least significant difference (LSD) was calculated only when the analysis of variance $F$-test was significant at the $P=0.05$ probability level.

\section{RESULTS}

\section{Precipitation and Plant-Available Water}

Annual precipitation (Fig. 1) during the 12-yr period from 1985 through 1996 varied from a low of $206 \mathrm{~mm}$ in 1988 to a high of $655 \mathrm{~mm}$ in 1993. The average annual precipitation during the study at the research site was $422 \mathrm{~mm}$, slightly more than the 409-mm 82-yr average at the Northern Great Plains Research Laboratory, Mandan, ND. Similar trends were observed for the April through August growing season precipitation, with a low of $132 \mathrm{~mm}$ in 1988 and a high of $602 \mathrm{~mm}$ in 1993 with a 12-yr site average of $296 \mathrm{~mm}$, compared with an 82 -yr average of $287 \mathrm{~mm}$. Three consecutive years, 1988 through 1990, provided an opportunity to obtain information on the effects of drought on SW production following SF in rotation. Total plant-available water was below $260 \mathrm{~mm}$ these three years (Fig. 1), thus severe plant water stress reduced growth and grain yield potential (Major et al., 1988; Nielsen and Halvorson, 1991). Annual and growing season precipitation in 1986, 1993, and 1995 were above average (Fig. 1). Total plant available water (Fig. 1) also was considerably above the average $(419 \mathrm{~mm})$ during these years with TPAW levels of 539, 740, and $667 \mathrm{~mm}$ for 1986, 1993, and 1995, respectively. Tillage system affected the level of spring TPAW with 431,418 , and $408 \mathrm{~mm}$ of TPAW $\left(\mathrm{LSD}_{0.05}=8 \mathrm{~mm}\right)$ for the NT, MT, and CT treatments, respectively.

\section{Soil Nitrate Nitrogen}

Spring soil $\mathrm{NO}_{3}-\mathrm{N}$ levels varied significantly with tillage system, $N$ rate, and year with significant tillage $X$ year, $\mathrm{N}$ rate $\times$ year, and tillage $\times \mathrm{N}$ rate $\times$ year interactions. Spring soil $\mathrm{NO}_{3}-\mathrm{N}$ levels (0- to $120-\mathrm{cm}$ depth) associated with the tillage $\times \mathrm{N}$ rate $\times$ year interaction are reported in Table 1. No differences were observed in spring soil $\mathrm{NO}_{3}-\mathrm{N}$ levels among tillage treatments when compared over $\mathrm{N}$ rates and years from 1985 through 1988. In 1989, spring soil $\mathrm{NO}_{3}-\mathrm{N}$ levels were significantly greater with MT than with NT and CT for the highest $\mathrm{N}$ rate. In 1990, spring soil $\mathrm{NO}_{3}-\mathrm{N}$ levels were greater with $\mathrm{CT}$ than $\mathrm{NT}$ at the highest $\mathrm{N}$ rate. In 1991, CT and MT had a higher level of soil $\mathrm{NO}_{3}-\mathrm{N}$ than $\mathrm{NT}$ at the low $\mathrm{N}$ rate. At the medium $\mathrm{N}$ rate, $\mathrm{CT}$ had a higher soil $\mathrm{NO}_{3}-\mathrm{N}$ level than MT and NT. At the high $\mathrm{N}$ rate, MT had a higher level of soil $\mathrm{NO}_{3}-\mathrm{N}$ than $\mathrm{CT}$ and NT. In 1992, CT had a higher level of soil $\mathrm{NO}_{3}-\mathrm{N}$ than MT and NT at the low and high $\mathrm{N}$ rates. At the medium $\mathrm{N}$ rate, soil $\mathrm{NO}_{3}-\mathrm{N}$ was greater with $\mathrm{CT}$ than MT. In 1993, there were no differences in soil $\mathrm{NO}_{3}-\mathrm{N}$ among tillage treatments at the low $\mathrm{N}$ rate, with $\mathrm{CT}$ having higher levels than NT at the medium N rate and CT and MT having higher levels than NT at the highest
Table 2. Spring wheat grain yields for the tillage $x$ rate $x$ year interaction $\dagger$ as grouped by level of total plant available water (TPAW).

\begin{tabular}{|c|c|c|c|c|}
\hline \multirow[b]{2}{*}{ Year } & \multirow[b]{2}{*}{ N Rate } & \multicolumn{3}{|c|}{ Grain yield } \\
\hline & & CT $\$$ & MT & NT \\
\hline & \multicolumn{4}{|c|}{$-\mathrm{kg} \mathrm{ha}^{-1}$} \\
\hline \multicolumn{5}{|c|}{$<300$ mm TPAW } \\
\hline 1988 & 34 & 64 & 83 & \\
\hline & 67 & 79 & 51 & 75 \\
\hline & 101 & 55 & 85 & \\
\hline 1989 & 34 & 527 & 556 & 682 \\
\hline & 67 & 570 & 597 & 620 \\
\hline & 101 & 589 & 592 & 719 \\
\hline 1990 & 34 & 848 & 882 & 970 \\
\hline & 67 & 940 & 1026 & 1020 \\
\hline & 101 & 928 & 945 & 1055 \\
\hline 1991 & 34 & 815 & 899 & 1037 \\
\hline & 67 & 867 & 866 & 987 \\
\hline & 101 & 910 & 940 & 1191 \\
\hline \multicolumn{5}{|c|}{ 300-400 mm TPAW } \\
\hline 1985 & 34 & 2073 & 1959 & 2191 \\
\hline & 67 & 1969 & 2001 & 2215 \\
\hline & 101 & 1869 & 1937 & 2095 \\
\hline 1987 & 34 & 909 & 1138 & 1313 \\
\hline & 67 & 1147 & 1551 & 1751 \\
\hline & 101 & 1148 & 1379 & 1763 \\
\hline \multirow[t]{3}{*}{1992} & 34 & 2568 & 3354 & 2585 \\
\hline & 67 & 2513 & 2826 & 2408 \\
\hline & 101 & 2817 & 3523 & 3505 \\
\hline \multirow[t]{3}{*}{1994} & 34 & 2099 & 2622 & 1590 \\
\hline & 67 & 2194 & 2699 & 2173 \\
\hline & 101 & 2024 & 2870 & 2344 \\
\hline \multirow[t]{3}{*}{1996} & 34 & 1502 & 1603 & 1725 \\
\hline & 67 & 1621 & 1678 & 2264 \\
\hline & 101 & 1492 & 1610 & 2451 \\
\hline \multirow{4}{*}{1986} & & Im TP & & \\
\hline & 34 & 1445 & 1418 & 1372 \\
\hline & 67 & 1979 & 1808 & 1641 \\
\hline & 101 & 2176 & 2136 & 1857 \\
\hline \multirow[t]{3}{*}{1993} & 34 & 1595 & 1597 & \\
\hline & 67 & 2154 & 2066 & 1927 \\
\hline & 101 & 2109 & 2109 & 2293 \\
\hline \multirow[t]{3}{*}{1995} & 34 & 1518 & 1475 & 1136 \\
\hline & 67 & 1747 & 1621 & 1414 \\
\hline & 101 & 1664 & 1618 & 1360 \\
\hline
\end{tabular}

$\dagger$ Interaction LSD $_{0.05}=220 \mathrm{~kg} \mathrm{ha}^{-1}$ (compare tillage within $\mathbf{N} \times$ year); $\mathbf{L S D}_{0.05}=215 \mathrm{~kg} \mathrm{ha}^{-1}$ (compare $\mathrm{N}$ rate within tillage $\times$ year).

$\ddagger$ CT, conventional till; MT, minimum till; NT, no till.

$\mathrm{N}$ rate. In 1994, MT had a higher level of soil $\mathrm{NO}_{3}-\mathrm{N}$ than NT at the lowest $\mathrm{N}$ rate, with $\mathrm{CT}$ and MT having higher levels than NT at the medium $\mathrm{N}$ rate and CT having higher levels than MT and NT at the highest N rate. In 1995 and 1996, no differences were observed among tillage treatments for each of the $\mathrm{N}$ rates. The data in Table 1 show that spring soil $\mathrm{NO}_{3}-\mathrm{N}$ in the soil profile had increased considerably following the drought years of 1988 through 1990, which experienced poor WW and $\mathrm{SF}$ yields and reduced $\mathrm{N}$ requirements (Halvorson et al., 1999a, b). The trend was for higher levels of soil $\mathrm{NO}_{3}-\mathrm{N}$ with increasing $\mathrm{N}$ rates from 1990 through 1994, with spring soil $\mathrm{NO}_{3}-\mathrm{N}$ levels in 1995 and 1996 approaching levels similar to those in 1985 at study initiation.

The tillage $\times$ year interaction also shows that spring soil $\mathrm{NO}_{3}-\mathrm{N}$ levels increased within all tillage systems from 1989 through 1992 (Fig. 2) following the drought years (Fig. 1). The NT treatment had less soil profile 


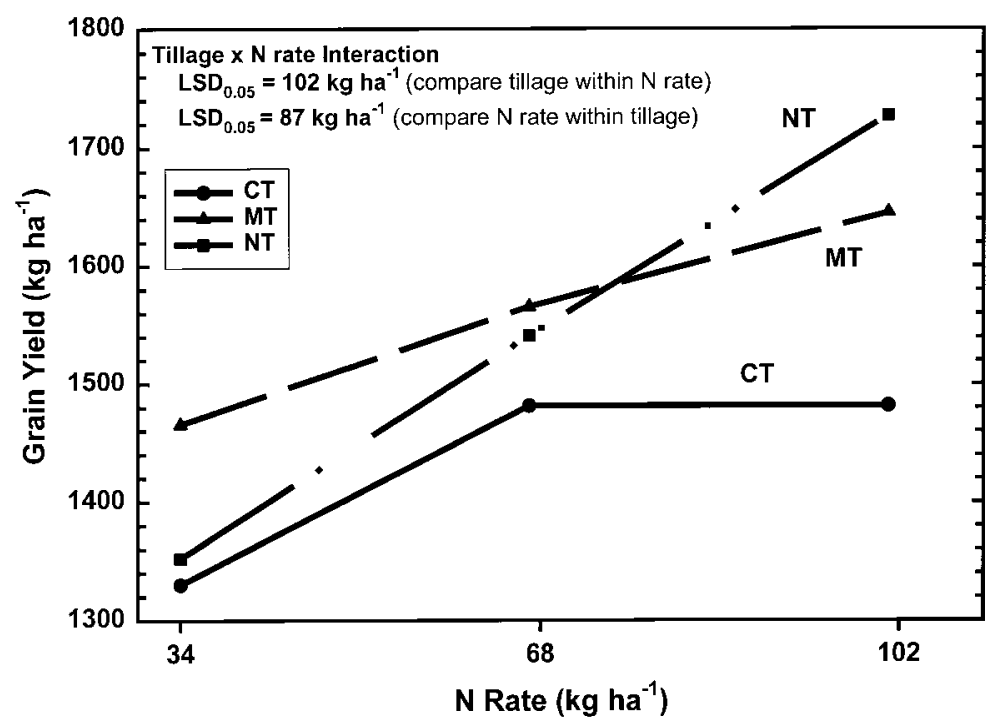

Fig. 4. Average 12-yr grain yield as a function of $\mathbf{N}$ rate for conventional-till (CT), minimum-till (MT), and no-till (NT) treatments.

$\mathrm{NO}_{3}-\mathrm{N}$ than CT from 1990 through 1994. Average spring soil $\mathrm{NO}_{3}-\mathrm{N}$ levels (0- to 120 -cm depth) were 122 , 113 , and $65 \mathrm{~kg} \mathrm{~N} \mathrm{ha}^{-1}$ for the CT, MT, and NT treatments, respectively. These trends probably reflect less $\mathrm{N}$ mineralization of soil organic matter in the NT system compared with the CT system, where tillage operations mix soil and crop residues. In fact, Wienhold and Halvorson (1998) showed that NT had a higher level of total $\mathrm{N}$ in the surface $15 \mathrm{~cm}$ of soil than MT and CT treatments after 10 crop years and that $\mathrm{N}$ mineralization potential (Wienhold and Halvorson, 1999) was greater with NT than with CT and MT.

The $\mathrm{N}$ rate $\times$ year interaction showed that spring soil $\mathrm{NO}_{3}-\mathrm{N}$ levels were similar for all $\mathrm{N}$ rates from 1985 through 1988 (Fig. 3). In 1989, soil $\mathrm{NO}_{3}-\mathrm{N}$ levels increased, with the greatest level of spring soil $\mathrm{NO}_{3}-\mathrm{N}$ associated with the $101 \mathrm{~kg} \mathrm{ha}^{-1} \mathrm{~N}$ rate. From 1989 through 1992, spring soil $\mathrm{NO}_{3}-\mathrm{N}$ levels increased with increasing $\mathrm{N}$ rate. Soil $\mathrm{NO}_{3}-\mathrm{N}$ levels began to decline in 1993 for all $\mathrm{N}$ rates, with the 34 and $67 \mathrm{~kg} \mathrm{ha}^{-1} \mathrm{~N}$ rates declining to 1985 levels. No fertilization in 1991 and 1992 along with fair to good SF yields (Halvorson et al., 1999b) from 1991 through 1994 prior to SW probably contributed to this decline in spring soil N levels. Spring soil $\mathrm{NO}_{3}-\mathrm{N}$ levels in 1994 were slightly greater than the 1993 levels for the 34 and $67 \mathrm{~kg} \mathrm{ha}^{-1} \mathrm{~N}$ rates. All spring soil $\mathrm{NO}_{3}-\mathrm{N}$ levels had declined to 1985 levels by 1996.

\section{Grain Yield}

Spring wheat grain yields were significantly affected by tillage system, $\mathrm{N}$ fertilization rate, cultivar, and years. However, significant tillage $\times \mathrm{N}$ rate, tillage $\times$ year, $\mathrm{N}$ rate $\times$ year, cultivar $\times$ year, tillage $\times N$ rate $\times$ year, and $\mathrm{N}$ rate $\times$ cultivar $\times$ year interactions for grain yield were present. The yearly data was grouped by level of

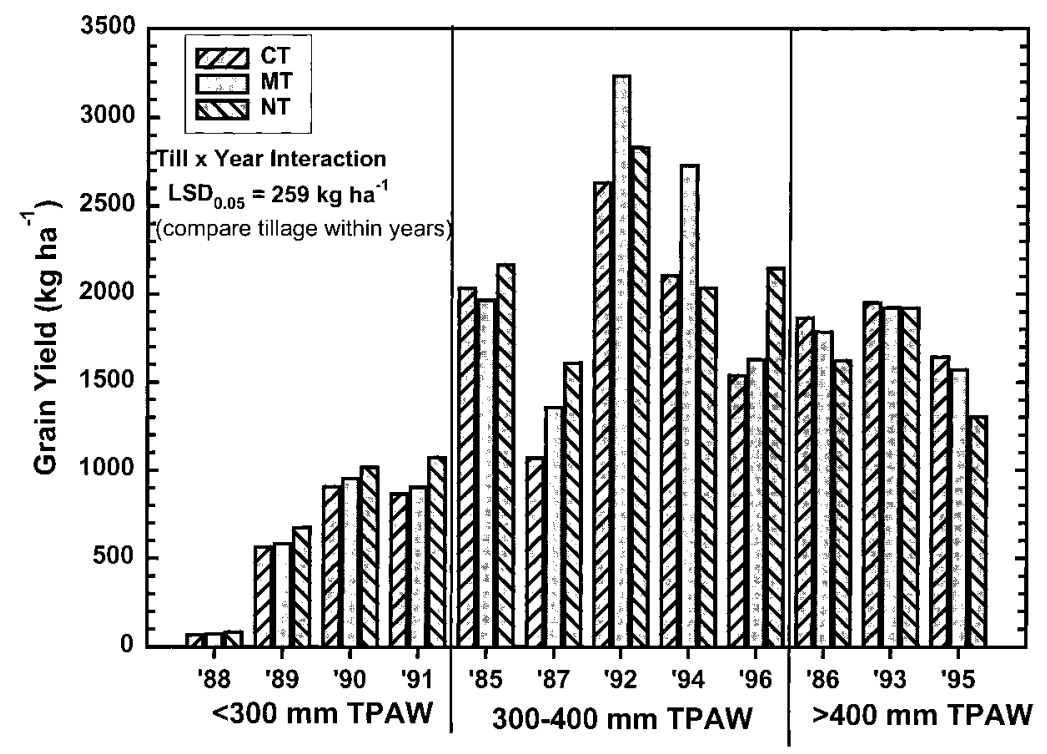

Fig. 5. Grain yield as a function of years, grouped by level of total plant available water (TPAW), for conventional-till (CT), minimum-till (MT), and no-till (NT) treatments. 


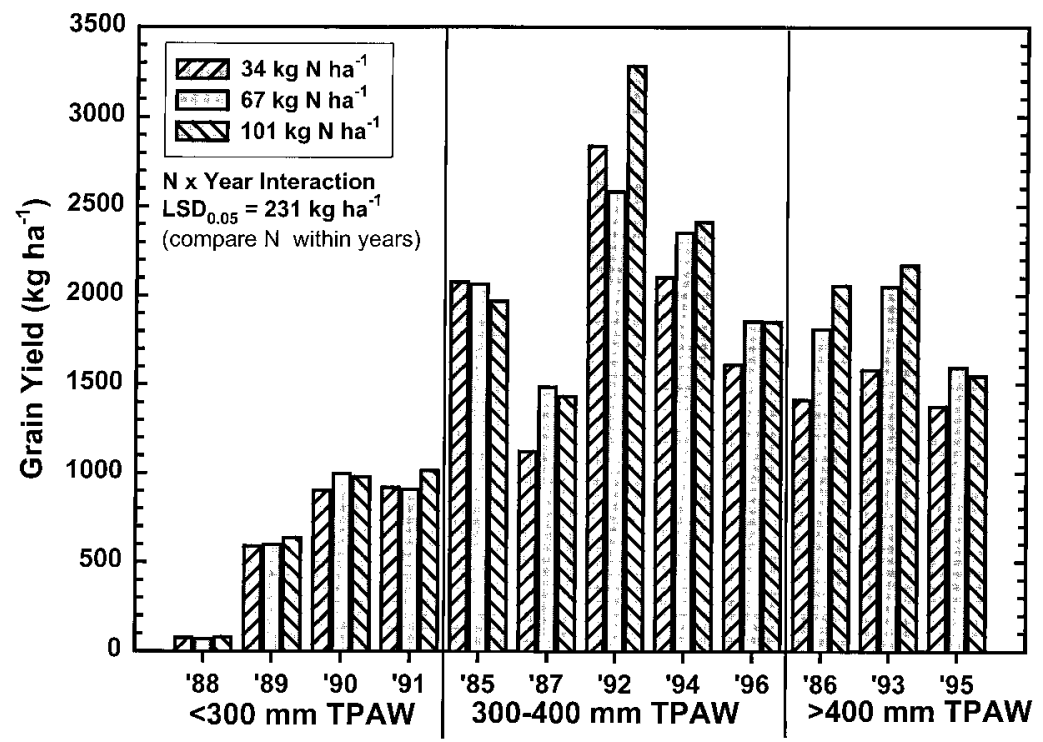

Fig. 6. Grain yield as a function of years, grouped by level of total plant available water (TPAW), for N rate treatments.

TPAW ( $<300 \mathrm{~mm}, 300-400 \mathrm{~mm}$, and $>400 \mathrm{~mm}$ ) to show the relationship of TPAW on SW yields.

Grain yields for the tillage $\times$ N rate $\times$ year interaction are shown in Table 2. During the years with $<300 \mathrm{~mm}$ TPAW, yields were lowest in 1988 and highest in 1991, with no differences among tillage treatments in 1988, 1989 , and 1990 when compared across $\mathrm{N}$ rates and years. In 1991, grain yields with NT were greater than with $\mathrm{CT}$ at the low and high $\mathrm{N}$ rates. In general, responses to $\mathrm{N}$ rates were nonsignificant during the years with $<300 \mathrm{~mm}$ TPAW; however, the greatest yields tended to be associated with NT and the highest $\mathrm{N}$ rate each year. Merrill et al. (1996) reported superior SW root growth in the NT system compared with the CT system, which would support the tendency for greater yields with NT.

During the years with 300 to $400 \mathrm{~mm}$ TPAW, grain yields (Table 2) were significantly higher with NT than with CT in 1985, 1987, and 1996 across all $\mathrm{N}$ rates, except for the low $\mathrm{N}$ rate in 1985. In 1987 and 1996, grain yields tended to increase with increasing $\mathrm{N}$ rates for NT, with no grain yield responses to N with CT and MT. In 1992 and 1994, grain yields with MT were greater than CT and $\mathrm{NT}$ over all $\mathrm{N}$ rates, except for the highest $\mathrm{N}$ rate in 1992 when NT yields equaled MT yields. In 1994, CT grain yields were greater than NT yields at the low N rate and NT yields were greater than CT yields at the high $\mathrm{N}$ rate. Yields in 1992 and 1994 tended to be the greatest at the highest N rate for MT and NT treatments. During the years when TPAW was $<400 \mathrm{~mm}$, NT and MT generally produced better grain yields than CT, partly because crop residue helped suppress evaporation so that the plants could use the water.

During the years with $>400 \mathrm{~mm}$ TPAW, grain yields (Table 2) were similar for all tillage treatments at the lowest $\mathrm{N}$ rates in 1986 and 1993, with significantly greater yields with CT and MT than with NT at the highest $\mathrm{N}$ rate in 1986. Grain yields increased with increasing $\mathrm{N}$ rates for all tillage treatments in 1986 and 1993. In 1995, CT and MT grain yields exceeded those of NT at the lowest and highest $\mathrm{N}$ rates, with $\mathrm{CT}$ yields exceeding those of NT at the medium N rate. In 1995, grain yields were maximized with the medium $\mathrm{N}$ rate for all tillage treatments. Grain yield responses to applications of 67 and $101 \mathrm{~kg} \mathrm{~N}^{-1}$ tended to be greater in years when TPAW was $>400 \mathrm{~mm}$ than in those years with less TPAW. The tendency for lower yields with NT in the wetter years in contrast to higher yields in

Table 3. Spring wheat grain yields for the $\mathbf{N}$ rate $\times$ cultivar $\times$ year interaction $\uparrow$ as grouped by level of total plant available water (TPAW).

\begin{tabular}{|c|c|c|c|c|}
\hline \multirow[b]{2}{*}{ Year } & \multirow[b]{2}{*}{ Cultivar } & \multicolumn{3}{|c|}{ Grain yield } \\
\hline & & $34 \mathrm{~kg} \mathrm{~N} \mathrm{ha}^{-1}$ & $67 \mathrm{~kg} \mathrm{~N} \mathrm{ha}^{-1}$ & $101 \mathrm{~kg} \mathrm{~N} \mathrm{ha} \mathbf{~}^{-1}$ \\
\hline \multicolumn{5}{|c|}{$<300 \mathrm{~mm}$ TPAW } \\
\hline 1988 & $\begin{array}{l}\text { Butte86 } \\
\text { Stoa }\end{array}$ & $\begin{array}{l}70 \\
79\end{array}$ & $\begin{array}{l}\mathbf{7 8} \\
\mathbf{5 8}\end{array}$ & $\begin{array}{l}88 \\
71\end{array}$ \\
\hline 1989 & $\begin{array}{l}\text { Butte86 } \\
\text { Stoa }\end{array}$ & $\begin{array}{l}613 \\
563\end{array}$ & $\begin{array}{l}\mathbf{5 9 5} \\
\mathbf{5 9 7}\end{array}$ & $\begin{array}{l}646 \\
621\end{array}$ \\
\hline 1990 & $\begin{array}{l}\text { Butte86 } \\
\text { Stoa }\end{array}$ & $\begin{array}{l}921 \\
879\end{array}$ & $\begin{array}{r}1060 \\
931\end{array}$ & $\begin{array}{r}1027 \\
925\end{array}$ \\
\hline 1991 & $\begin{array}{l}\text { Butte86 } \\
\text { Stoa }\end{array}$ & $\begin{array}{r}1059 \\
775\end{array}$ & $\begin{array}{l}984 \\
829\end{array}$ & $\begin{array}{r}1081 \\
946\end{array}$ \\
\hline \multicolumn{5}{|c|}{ 300-400 mm TPAW } \\
\hline 1985 & $\begin{array}{l}\text { Butte86 } \\
\text { Stoa }\end{array}$ & $\begin{array}{l}2205 \\
1944\end{array}$ & $\begin{array}{l}2121 \\
2001\end{array}$ & $\begin{array}{l}1984 \\
1950\end{array}$ \\
\hline 1987 & $\begin{array}{l}\text { Butte86 } \\
\text { Stoa }\end{array}$ & $\begin{array}{l}1158 \\
1082\end{array}$ & $\begin{array}{l}1593 \\
1373\end{array}$ & $\begin{array}{l}1438 \\
1422\end{array}$ \\
\hline 1992 & $\begin{array}{l}\text { Butte86 } \\
\text { Stoa }\end{array}$ & $\begin{array}{l}2978 \\
2693\end{array}$ & $\begin{array}{l}2788 \\
2377\end{array}$ & $\begin{array}{l}3465 \\
3099\end{array}$ \\
\hline 1994 & $\begin{array}{l}\text { Butte86 } \\
\text { Stoa }\end{array}$ & $\begin{array}{l}2155 \\
2052\end{array}$ & $\begin{array}{l}2399 \\
2311\end{array}$ & $\begin{array}{l}2504 \\
2320\end{array}$ \\
\hline 1996 & $\begin{array}{l}\text { Butte86 } \\
\text { Stoa }\end{array}$ & $\begin{array}{l}1600 \\
1620\end{array}$ & $\begin{array}{l}1964 \\
1745\end{array}$ & $\begin{array}{l}1867 \\
1835\end{array}$ \\
\hline \multicolumn{5}{|c|}{$>400 \mathrm{~mm}$ TPAW } \\
\hline 1986 & $\begin{array}{l}\text { Butte86 } \\
\text { Stoa }\end{array}$ & $\begin{array}{l}1597 \\
1226\end{array}$ & $\begin{array}{l}1912 \\
1706\end{array}$ & $\begin{array}{l}2222 \\
1890\end{array}$ \\
\hline 1993 & $\begin{array}{l}\text { Butte86 } \\
\text { Stoa }\end{array}$ & $\begin{array}{l}1663 \\
1498\end{array}$ & $\begin{array}{l}2209 \\
1889\end{array}$ & $\begin{array}{l}2262 \\
2079\end{array}$ \\
\hline 1995 & $\begin{array}{l}\text { Butte86 } \\
\text { Stoa }\end{array}$ & $\begin{array}{l}1611 \\
1142\end{array}$ & $\begin{array}{l}1803 \\
1385\end{array}$ & $\begin{array}{l}1840 \\
1255\end{array}$ \\
\hline
\end{tabular}

$\dagger$ Interaction $\mathbf{L S D}_{0.05}=\mathbf{1 2 5} \mathbf{~ k g ~ h a}^{-1}$ (compare $\mathbf{N}$ rate within cultivar $\times$ year); LSD $=116 \mathrm{~kg} \mathrm{ha}^{-1}$ (compare cultivar within $\mathrm{N}$ rates $\times$ year). 


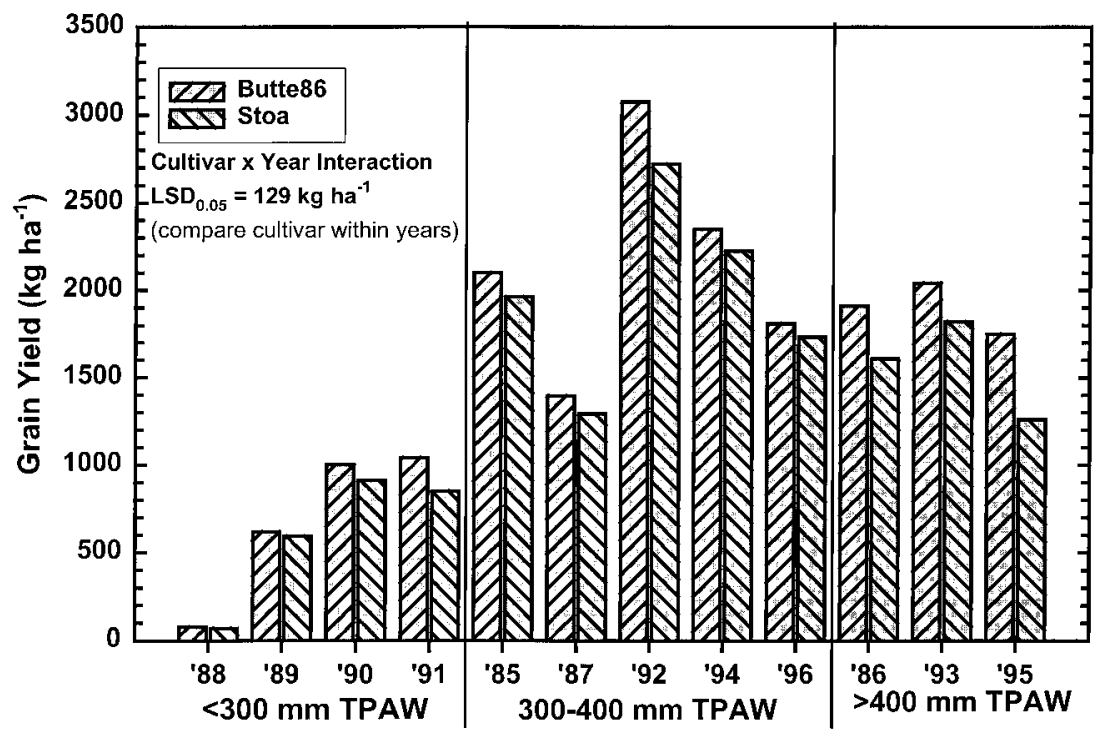

Fig. 7. Grain yield as a function years, grouped by level of total plant available water (TPAW), for spring wheat cultivars.

the drier years when compared with yields with CT and MT partly explains the significant tillage $\times N$ rate $\times$ year interaction. Residues were not as important to water conservation and evaporation suppression during years with $>400 \mathrm{~mm}$ TPAW. In addition, responses to $\mathrm{N}$ at the two highest rates were probably minimized by the high level of spring soil $\mathrm{N}$ present at planting most years. Campbell et al. (1993a, b) reported that soil N became more important to SW yields than fertilizer $\mathrm{N}$ with increasing years of adequate $\mathrm{N}$ fertilization in an annual cropping system. This supports our observations in this study.

Grain yields in the $>400 \mathrm{~mm}$ TPAW group were generally equal to or less than those within the 300 to $400 \mathrm{~mm}$ TPAW group. One reason for grain yields not increasing above those within the 300 to $400 \mathrm{~mm}$ TPAW group would be an increase in leaf spot disease severity associated with higher moisture levels, which reduced yield potential (Krupinsky et al., 1997, 1998). A contributing factor to lower yields at the $34 \mathrm{~kg} \mathrm{~N} \mathrm{ha}^{-1}$ could be related to an increase in disease severity. When evaluating SW plants for leaf spot diseases during this study, differences among $\mathrm{N}$ treatments were evident for nearly half $(45 \%)$ of the ratings. Higher levels of disease severity were associated with the $34 \mathrm{~kg} \mathrm{~N} \mathrm{ha}^{-1}$ treatment compared with the higher $\mathrm{N}$ treatments. This indicated that $\mathrm{N}$ level had an influence on leaf spot diseases and emphasized the importance of providing adequate $\mathrm{N}$ nutrition in continuous cropping systems (Krupinsky et al., 1997, 1998).

The tillage $\times \mathrm{N}$ interaction shows that $\mathrm{SW}$ grain yields with MT were greater than those with CT and NT at $34 \mathrm{~kg} \mathrm{ha}^{-1} \mathrm{~N}$ (Fig. 4). Grain yields at the $101 \mathrm{~kg} \mathrm{ha}^{-1}$ $\mathrm{N}$ rate were in the order $\mathrm{NT}=\mathrm{MT}>\mathrm{CT}$. The greatest 12-yr average SW grain yield $\left(1727 \mathrm{~kg} \mathrm{ha}^{-1}\right)$ resulted with NT and the highest $\mathrm{N}$ rate. The benefit of using NT and MT systems over CT systems for SW production in an annual cropping system with adequate $\mathrm{N}$ fertilization is depicted in Fig. 4.
Discussion of the tillage $\times$ year (Fig. 5) and N rate $\times$ year (Fig. 6) interactions for grain yield will be minimal due to the extensive discussion of the tillage $\times \mathrm{N}$ rate $X$ year interaction above. Data trends observed in Fig. 5 and Fig. 6 are similar to those discussed above for the grain yield data in Table 2 .

Grain yields for the $\mathrm{N}$ rate $\times$ cultivar $\times$ year interaction are reported in Table 3. During the years with $<300 \mathrm{~mm}$ TPAW, there were no grain yield responses to $\mathrm{N}$ with Stoa; however, grain yields were maximized at the medium $\mathrm{N}$ rate with Butte86 in 1990. During the years with 300 to $400 \mathrm{~mm}$ TPAW, grain yield responses to $\mathrm{N}$ rate varied. In 1985, Stoa did not respond to $\mathrm{N}$ fertilization but Butte86 grain yields decreased with increasing $\mathrm{N}$ rate. In 1987, grain yields with the medium and high $\mathrm{N}$ rates exceeded those of the low $\mathrm{N}$ rate for both cultivars. In 1992, the low and high $\mathrm{N}$ rates produced a greater yield than with the medium $\mathrm{N}$ rate for both cultivars. In 1994 and 1996, the medium and high $\mathrm{N}$ rates produced higher yields than the low $\mathrm{N}$ rate for both cultivars. During the years with $>400 \mathrm{~mm}$ TPAW, both cultivars obtained their greatest yields with the highest N rate, with the exception of Stoa in 1995. In 1993 and 1995, grain yields were similar for the medium and high $\mathrm{N}$ rates for Butte86. Grain yields at the medium $\mathrm{N}$ rate were greater than with the high or low $\mathrm{N}$ rates in 1995 for Stoa. In general, grain yields for Butte86 tended to be greater than those of Stoa at all $\mathrm{N}$ rates in $1985,1991,1992,1993$, and 1995.

The cultivar $\times$ year interaction effects on grain yields are shown in Fig. 7. Grain yields were greater for Butte86 than for Stoa in 1985, 1986, 1991, 1992, 1993, and 1995 (6 out of the 12 years of this study). Stoa grain yields equaled those of Butte 86 during the other six years. In this study, Butte 86 generally reached the heading and grain filling growth stages about $6 \mathrm{~d}$ earlier than Stoa, thereby escaping some of the effects of plant diseases and late summer drought stress. This may partially explain the greater yields with Butte86 over Stoa 
in some years. The overall impact of SW cultivar on grain yields in this study was small.

Grain yields for the NT, MT, and CT treatments averaged 1540,1558 , and $1431 \mathrm{~kg} \mathrm{ha}^{-1}$, respectively. Average grain yields were 1383,1529 , and $1618 \mathrm{~kg} \mathrm{ha}^{-1}$ for the 34,67 , and $101 \mathrm{~kg} \mathrm{~N}^{-1}$ treatments, respectively. Grain yields for Butte86 and Stoa averaged 1599 and 1421 $\mathrm{kg} \mathrm{ha}^{-1}$, respectively.

\section{SUMMARY}

The results of this study show that SW grain yields following SF in rotation are generally enhanced using MT and NT systems compared with CT during most years with adequate $\mathrm{N}$ fertility. Grain yields tended to be greatest with NT compared with CT during those years with $<400 \mathrm{~mm}$ TPAW. In wetter years, CT treatments generally produced greater SW yields than NT, particularly at low $\mathrm{N}$ rates. Leaf spot disease pressure was greater during the wetter years and at the low $\mathrm{N}$ rate (Krupinsky et al., 1997, 1998). The results show that during extremely dry years (e.g., 1988 through 1990), reduced tillage treatments did not store enough additional water to significantly enhance yield potential over that of the CT system. Responses to $\mathrm{N}$ fertilization were insignificant during these dry years, which resulted in increased residual spring soil $\mathrm{NO}_{3}-\mathrm{N}$ levels. Responses to $\mathrm{N}$ fertilization were similar for both cultivars during the average and wetter years. Butte 86 grain yields were greater than those of Stoa in 6 out of 12 years, three of which were years with $>400 \mathrm{~mm}$ TPAW and two years with 300 to $400 \mathrm{~mm}$ TPAW. Grain yields were similar for both cultivars for all other years. The highest 12-yr average grain yield was obtained with the highest $\mathrm{N}$ rate and NT.

Spring wheat yield responses in this study are in agreement with annual cropping SW yields reported by Aase and Schaefer (1996) using NT, Halvorson and Black (1985), and Black et al. (1981) in northeastern Montana. In 6 out of the 12 years in this study, spring wheat yields exceeded the average 2-yr, SW-fallow yields $\left(1737 \mathrm{~kg} \mathrm{ha}^{-1}\right)$ reported for five southcentral North Dakota counties near the study site for 1989 through 1996 (Beard and Hamlin, 1995; Beard and Waldhaus, 1997). In two years, yields were 77 and $87 \%$ of SW-fallow yields; in two years, yields were $54 \%$ of SW-fallow yields; and in two years, yields were about $34 \%$ of SWfallow yields.

These results indicate that farmers in the northern Great Plains can successfully produce SW following SF in annual cropping rotations that do not include a fallow period. During production periods with low soil water recharge following sunflower in rotation, farmers may want to consider producing a crop with lower water-use requirements than spring wheat to avoid uneconomical spring wheat yields. Fallow following sunflower should be considered as the last alternative because of a high soil erosion potential.

\section{ACKNOWLEDGMENTS}

The authors acknowledge the contribution of the Area IV Soil Conservation Districts in North Dakota for providing the land and assisting with financial resources to conduct this longterm study, the assistance of Dr. Gary Richardson, USDAARS Statistician, Fort Collins, CO, with the statistical analyses, and the assistance of F. Jacober, J. Harms, L. Renner, M. Hatzenbuhler, and G. Brucker in conducting the study and collecting the field and laboratory data.

\section{REFERENCES}

Aase, J.K., and L.L. Reitz. 1989. Effects of tillage practices and crop sequence on spring grain production in the northern Great Plains. Appl. Agric. Res. 4:30-36.

Aase, J.K., and G.M. Schaefer. 1996. Economics of tillage practices and spring wheat and barley crop sequence in the northern Great Plains. J. Soil Water Conserv. 51:167-170.

Beard, L.W., and W.G. Hamlin. 1995. North Dakota agricultural statistics 1995. Ag Statistics No. 64. USDA and North Dakota State Univ., Fargo.

Beard, L.W., and E. Waldhaus. 1997. North Dakota agricultural statistics 1997. Ag Statistics No. 66. USDA and North Dakota State Univ., Fargo.

Black, A.L., P.L. Brown, A.D. Halvorson, and F.H. Siddoway. 1981. Dryland cropping strategies for efficient water-use to control saline seeps in the northern Great Plains, U.S.A. Agric. Water Manage. 4:295-311.

Black, A.L., and D.L. Tanaka. 1997. A conservation tillage-cropping systems study in the northern Great Plains of the United States. p. 335-342. In E.A. Paul, K. Paustian, E.T. Elliott, and C.V. Cole (ed.) Soil organic matter in temperate agroecosystems-Long-term experiments in North America. CRC Press, Boca Raton, FL.

Campbell, C.A., F. Selles, R.P. Zentner, and B.G. McConkey. 1993b. Available water and nitrogen effects on yield components and grain nitrogen of zero-till spring wheat. Agron. J. 85:114-120.

Campbell, C.A., R.P. Zentner, F. Selles, B.G. McConkey, and F.B Dyck. 1993a. Nitrogen management for spring wheat grown annually on zero-tillage: Yields and nitrogen use efficiency. Agron. J. 85:107-114.

Deibert, E.J., E. French, and B. Hoag. 1986. Water storage and use by spring wheat under conventional tillage and no-till in continuous and alternate crop-fallow systems in the northern Great Plains. J. Soil Water Conserv. 41:53-58.

Dhuyvetter, K.C., C.R. Thompson, C.A. Norwood, A.D. Halvorson. 1996. Economics of dryland cropping systems in the Great Plains: A review. J. Prod. Agric. 9:216-222.

Hall, E.F., and F.A. Cholick. 1989. Cultivar $\times$ tillage interaction of hard red spring wheat cultivars. Agron. J. 81:789-792.

Halvorson, A.D. 1984. Saline-seep reclamation in the northern Great Plains. Trans. ASAE 27:773-778.

Halvorson, A.D. 1990a. Management of dryland saline seeps. p. 372 392. In K.K. Tanji (ed.) Agricultural salinity assessment and management. ASCE Manuals and Reports on Engineering Practice No. 71. Am. Soc. Civil Eng., New York.

Halvorson, A.D. 1990b. Cropping systems and N fertilization for efficient water use in the central Great Plains. p. 117-123. In Proc. Great Plains Conservation Tillage Symposium. Great Plains Agric. Council Bull. No. 131. Great Plains Agric. Council, Fort Collins, CO.

Halvorson, A.D., and A.L. Black. 1974. Saline-seep development in dryland soils of northeastern Montana. J. Soil Water Conserv. 29: $77-81$.

Halvorson, A.D., and A.L. Black. 1985. Long-term dryland crop responses to residual phosphorus fertilizer. Soil Sci. Soc. Am. J. 49: 928-933.

Halvorson, A.D., A.L. Black, J.M. Krupinsky, and S.D. Merrill. 1999a. Dryland winter wheat response to tillage and $\mathrm{N}$ within an annual cropping system. Agron. J. 91:702-707.

Halvorson, A.D., A.L. Black, J.M. Krupinsky, S.D. Merrill, and D.L. Tanaka. 1999b. Sunflower response to tillage and N under intensive cropping in wheat rotation. Agron. J. 91:637-642.

Halvorson, A.D., and C.A. Reule. 1980. Alfalfa for hydrologic control of saline seeps. Soil Sci. Soc. Am. J. 44:370-374.

Halvorson, A.D, and C.A. Reule. 1994. Nitrogen fertilizer requirements in an annual dryland cropping system. Agron. J. 86:315-318

Krupinsky, J.M., A.D. Halvorson, and A.L. Black. 1997. Diseases 
in zero-till cereal crops. p. 93-102. In Proc. Nineteenth Annual Manitoba-North Dakota Zero Tillage Workshop. 27-29 Jan 1997. Manitoba-North Dakota Zero Tillage Farmers' Assoc., Brandon, MB, Canada.

Krupinsky, J.M., A.D. Halvorson, and A.L. Black. 1998. Leaf spot diseases of wheat in a conservation tillage study. p. 322-326. In E. Duveiller, H.J. Dubin, J. Reeves, and A. McNab (ed.) Helminthosporium blights of wheat: Spot blotch and tan spot. CYMMT, Mexico, D.F.

Lachat Instruments. 1989. Nitrate in $2 \mathrm{M} \mathrm{KCl}$ soil extracts. QuikChem Method No. 12-107-04-1-B. Lachat Instruments, Milwaukee, WI.

Major, D.J., B.L. Blad, A. Bauer, J.L. Hatfield, K.G. Hubbard, E.T. Kanemasu, and R.J. Reginato. 1988. Winter wheat grain yield response to water and nitrogen on the North American Great Plains. Agric. For. Meteorol. 44:141-149.

McGee, E.A., G.A. Peterson, and D.G. Westfall. 1997. Water storage efficiency in no-till dryland cropping systems. J. Soil Water Conserv. 52:131-136.

Merrill, S.D., A.L. Black, and A. Bauer. 1996. Conservation tillage affects root growth of dryland spring wheat under drought. Soil Sci. Soc. Am. J. 60:575-583.

Merrill, S.D., A.L. Black, D.W. Fryrear, A. Saleh, T.M. Zobeck, A.D. Halvorson, D.L. Tanaka. 1999. Soil wind erosion hazard of spring wheat-fallow as affected by long-term climate and tillage. Soil Sci. Soc. Am. J. 63:1768-1777.
Merrill, S.D., A.L. Black, and T.M. Zobeck. 1995. Overwinter changes in dry aggregate size distribution influencing wind erodibility in a spring wheat-summer fallow cropping system. J. Minn. Acad. Sci. 59:27-36.

Nielsen, D.C., and A.D. Halvorson. 1991. Nitrogen fertility influence on water stress and yield of winter wheat. Agron. J. 83:1065-1070.

Peterson, G.A., A.J. Schlegel, D.L. Tanaka, and O.R. Jones. 1996. Precipitation Use Efficiency as affected by cropping and tillage systems. J. Prod. Agric. 9:180-186.

SAS Institute Inc. 1991. SAS/STAT user's guide, Version 6, 4th ed. SAS Institute, Cary, NC.

Tanaka, D.L., and R.L. Anderson. 1997. Soil water storage and precipitation storage efficiency of conservation tillage systems. J. Soil Water Conserv. 52:363-367.

Technicon Industrial Systems. 1973. Nitrate and nitrite in water and wastewater. Industrial method no. 100-70W. Technicon Industrial Systems, Tarrytown, NY.

Wienhold, B.J., and A.D. Halvorson. 1998. Cropping system influence on several soil quality attributes in the northern Great Plains. J. Soil Water Conserv. 53: 254-258.

Wienhold, B.J., and A.D. Halvorson. 1999. Nitrogen mineralization responses to cropping, tillage, and nitrogen rate in the northern Great Plains. Soil Sci. Soc. Am. J. 63:192-196.

\title{
Cover Crops for Sweet Corn Production in a Short-Season Environment
}

\author{
Tim Griffin*, Matt Liebman, and John Jemison Jr.
}

\begin{abstract}
Legume cover crops can supply all or most of the $N$ required by a subsequent crop if legume biomass is of sufficient quantity and $\mathbf{N}$ mineralization is approximately synchronous with crop demand. Three 2-yr crop rotation cycles were conducted on a Lamoine silt loam (fine, illitic, nonacid, frigid Aeric Epiaquept) soil in Maine to (i) evaluate biomass and $\mathbf{N}$ accumulation of alfalfa (Medicago sativa L.), winter rye (Secale cereale $\mathrm{L}_{\text {.) }}$, and hairy vetch (Vicia villosa Roth subsp. villosa ) plus winter rye cover crops; (ii) determine sweet corn (Zea mays $\mathbf{L}$.) response to legume and fertilizer $\mathbf{N}$ sources in a barley (Hordeum vulgare L.)-sweet corn rotation; and (iii) assess the accuracy of the presidedress soil nitrate test (PSNT) and leaf chlorophyll $\mathbf{N}$ test (LCNT) for distinguishing N-responsive and nonresponsive sweet corn. Both legumes accumulated more $\mathbf{N}$ than rye grown alone, although total biomass was similar. Sweet corn following rye always exhibited a linear response to $\mathbf{N}$ fertilizer (up to $156 \mathrm{~kg} \mathrm{~N} \mathrm{ha}^{-1}$ ), but generally exhibited no response to added $\mathrm{N}$ following either alfalfa or hairy vetch plus winter rye (VR). Both PSNT and LCNT were $\mathbf{7 5} \%$ accurate in identifying plots responsive to additional fertilizer $\mathbf{N}$. The legume cover crops grown were able to replace all or nearly all of the $\mathbf{N}$ fertilizer required by a subsequent sweet corn crop, with fertilizer replacement values (FRVs) of 58 to $156 \mathrm{~kg} \mathrm{~N} \mathrm{ha}^{-1}$ in a short-season environment. These cover crops are a viable alternative source of $\mathrm{N}$, greatly reducing or eliminating the need for $\mathbf{N}$ fertilizer.
\end{abstract}

$\mathrm{P}$ Roduction systems that utilize N-fixing legumes as a primary $\mathrm{N}$ source for subsequent nonlegume crops include full-season green manure crops, interseeded le-

T. Griffin and J. Jemison Jr., Cooperative Extension, University of Maine, 495 College Avenue., Orono, ME 04473-1294. M. Liebman, Department of Agronomy, 3218 Agronomy Hall, Iowa State University, Ames, IA 50011-1010. Maine Agric. Forest Exp. Stn. Publ. 2367. Partial Funding from USDA-SARE, Project ANE92-31. Received 3 May 1999.*Corresponding author (tgriffin@umext.maine.edu).

Published in Agron. J. 92:144-151 (2000). gumes, and cover crops. Each of these options present significant management challenges to producers interested in reducing fertilizer $\mathrm{N}$ inputs or producing crops without fertilizer N. For example, full-season green manure crops, while potentially having the greatest impact on soil quality and pest/weed cycles (Altieri, 1995; Biederbeck et al., 1998), may not be economically viable because of the loss of income from that field for an entire growing season. Interseeding legumes with or into a standing crop is common in small grains like wheat (Triticum aestivum L.) and oat (Avena sativa L.). Bruulsema and Christie (1987), Hesterman et al. (1992), and Stute and Posner (1995) demonstrated that this system can result in significant contributions of $\mathrm{N}$ to a subsequent corn crop. However, interseeding into a widely spaced row crop like corn or soybean [Glycine $\max (\mathrm{L}$.) Merr] may require specialized equipment and additional field operations, and competition between the interseeded and main crops also can be problematic (Kumwenda et al., 1993).

Cover crops, generally grown over the winter between harvest of one crop and planting of a subsequent crop, can overcome at least some of the obstacles associated with green manure and interseeded crops. It is welldocumented that cover crops can supply sufficient $\mathrm{N}$ for production of a subsequent grain crop with little or no supplemental N fertilizer. McVay et al. (1989) found minimal corn yield response to $\mathrm{N}$ fertilizer following hairy vetch or crimson clover (Trifoilium incarnatum L.) cover crops, compared with corn following wheat. Burket et al. (1997) compared sweet corn yield following clover (Trifolium pratense L.), rye, and rye plus pea

Abbreviations: FRV, fertilizer replacement value; LCNT, leaf chlorophyll N test; PSNT, presidedress soil nitrate test; VR, hairy vetch plus winter rye; DM, dry matter. 